\title{
Psychosomatic Aspects of Urinary Incontinence in Women
}

\author{
Psychosomatische Aspekte der Harninkontinenz der Frau
}

Authors

Affiliations

\section{G. Debus ${ }^{1}$, R. Kästner ${ }^{2}$}

${ }^{1}$ Frauenklinik, Klinikum Dachau, Dachau

${ }^{2}$ Frauenklinik Maistraße, Universitätsklinik München, München
Key words

- urinary incontinence

- quality of life

- urogynaecology

- psychosomatics

- sexuality

Schlüsselwörter

- Harninkontinenz

- Lebensqualität

- Urogynäkologie

- Psychosomatik

- Sexualität

Deutschsprachige Zusatzinformationen online abrufbar unter: www.thieme-connect.de/ ejournals/toc/gebfra

$\begin{array}{ll}\text { received } & 8.8 .2013 \\ \text { revised } & 8.1 .2015 \\ \text { accepted } & 11.1 .2015\end{array}$

Bibliography

Dol http://dx.doi.org/

10.1055/s-0034-1396257

Geburtsh Frauenheilk 2015; 75:

165-169 ๑ Georg Thieme

Verlag KG Stuttgart · New York . ISSN 0016-5751

\section{Abstract \\ $\nabla$}

Urinary incontinence in women is a common problem. With increasing age its prevalence and severity of its manifestations increase. Among nursing home residents the frequency is between 43 and $77 \%, 6$ to $10 \%$ of all admissions to nursing homes are due to urinary incontinence. The risk for urinary incontinence among women with cognitive deficits is 1.5- to 3.4-fold higher than for women without mental disorders. The most common form is stress incontinence (50\%), followed by mixed stress-urge incontinence $(40 \%)$ and purely urge incontinence $(\mathrm{OAB}=$ overactive bladder, $20 \%$ ). With regard to its cause, the latter remains unclarified in about $80 \%$ of the cases. It is often difficult to treat. There are also cases in which urge incontinence is related to traumatic events. In such cases behavioural and psychotherapeutic options may be helpful. Almost inevitably every form of incontinence has psychological consequences: shame and insecurity are often results of uncontrolled loss of urine. Among others, in the long term, they lead to the avoidance of social contacts and possibly to depression and isolation. Consideration of the psychosomatics is important in the therapy for female urinary incontinence from three points of view: 1) the efficacy of treatment is better suited to the patient, 2) the treatment costs are lower, 3 ) the professional satisfaction of the responsible physician increases.

\section{Introduction \\ $\nabla$}

Urinary incontinence is an increasing health problem in our rapidly ageing society that is often not disclosed for a long time by the victims and is associated with appreciable costs. In the USA the

\section{Zusammenfassung \\ $\nabla$}

Harninkontinenz bei der Frau ist ein häufiges Problem. Mit dem Alter steigt ihre Prävalenz und die Schwere ihrer Ausprägung. Bei Bewohnerinnen von Pflegeheimen beträgt die Häufigkeit $43-77 \%$, 6-10\% der Heimeinweisungen erfolgen wegen Harninkontinenz. Das Risiko für eine Harninkontinenz ist bei Frauen mit kognitivem Defizit um den Faktor 1,5-3,5 erhöht gegenüber Frauen mit ungestörter mentaler Funktion. Die häufigste Harninkontinenz ist die Belastungsinkontinenz (50\%), gefolgt von der gemischten BelastungsDrang-Inkontinenz (40\%) und der reinen Dranginkontinenz (ÜAB = überaktive Blase, 20\%). Letztere bleibt hinsichtlich ihrer Ursache in ca. 80\% der Fälle ungeklärt. Sie ist gelegentlich schwierig zu behandeln. Es gibt Fälle, in denen eine Dranginkontinenz im Zusammenhang steht mit traumatisierenden Ereignissen. Dann können zusätzliche verhaltenstherapeutische und psychotherapeutische Ansätze hilfreich sein. Fast zwangsläufig hat jede Form von Inkontinenz psychische Folgen: mit unkontrolliertem Urinverlust sind häufig Scham und Unsicherheit verbunden. Sie führen u.U. langfristig zur Vermeidung von sozialen Kontakten, und evtl. zu Depressivität und Vereinsamung. Unter 3 Gesichtspunkten ist die Berücksichtigung der Psychosomatik bei der Therapie der weiblichen Inkontinenz wichtig: 1. die Effizienz der Behandlung wird der Patientin besser gerecht, 2. die Kosten der Behandlung sinken, 3. die Arbeitszufriedenheit der behandelnden Ärzte und Ärztinnen steigt.

annual costs generated by urgency urinary incontinence are estimated at almost \$82.6 in 2015 with growing tendency [1].

The prevalence of urinary incontinence increases with increasing age. Thus, Buckley et al. [2] and Markland et al. [3] reported that 25 to $57 \%$ of all 
female patients whom they had interviewed had involuntarily lost urine at least once in the previous year. The frequency according to age groups was described by Nygaard et al. [4] as follows:

- 20-39 years: $7 \%$

- 40-59 years: $17 \%$

- 60-79 years: $23 \%$

- 80 years and more: $32 \%$

The number of incontinent women in nursing homes is markedly higher, ranging from 43 to $77 \%$ [5]. Incontinence is the reason for $6-10 \%$ of all admissions to nursing homes. The risk for incontinence in women with dementia is 1.5 - to 3.5 -fold higher than that for women with unimpaired brain function [6]. In this context, the so-called Hakim triad should be mentioned; a clinical entity that is often missed but which in cases of normal pressure hydrocephalus from the 6th decade onwards is a cause of dementia, urinary incontinence and gait disorders, the relief of which represents a causal therapy [7].

During pregnancy, urinary incontinence is also a common phenomenon affecting between 30 and $60 \%$ of all pregnant women and which regresses in more than half of the women after delivery [8]. Evidence-based factors to avoid incontinence due to childbirth and pelvic floor injuries have been described in detail [9]. With advancing age, the incidence of incontinence also increases; urge incontinence which only plays a minor role in young women, increases more than stress incontinence, especially in the postmenopausal period. Although the following pathogenic processes predispose to incontinence, incontinence is not necessarily a component of the ageing process:

- myogenic increase of detrusor activity with detrusor instability

- loss of detrusor contractility with reduction of urine flow

- degeneration of bladder wall muscle cells and collagen deposits in the interstitial spaces [10]

- atrophy of the superficial and intermediary epithelium layers of the urethral mucous membranes (irritation, loss of compliance) [11]

- increased elimination of liquids during the night [12].

When the afflicted women finally pluck up the courage to consult a physician, gynaecologists and general practitioners are often the first points of call. The aim of the present review article is to help these physicians to initiate first effective measures in addition to a comprehensive case history with just a few orienting examinations.

In this article the relationship between the symptoms and the complex and complicated coupling of bladder function with brain function is presented, in addition, indications and options for the psychosomatic treatment of the patients are illustrated, especially when psychogenic causes for the incontinence are uncovered.

\section{Incontinence and Quality of Life}

$\nabla$

Incontinence causes a major reduction in the quality of life for women of all age groups including even elderly and frail nursing home residents [13]. In a survey of 293 patients presenting for clarification of incontinence, Kelleher et al. [14] also found that patients with detrusor instability experience a greater impairment of their quality of life than do other incontinence patients. With a specific questionnaire, namely King's questionnaire, a very good instrument has been developed for the evaluation of the mental impairments of women due to incontinence. The validated German version of the questionnaire [15] can be obtained free of charge via http://www.iciq.net/index.html.

With the help of this questionnaire, Hensel et al. [16] were able to demonstrate prospectively in 53 patients with combined stress incontinence and overactive bladders (OAB) that the placement of a suburethral tape resulted in a significant improvement in quality of life.

With ca. $40 \%$ of all incontinences in women urge incontinence is a frequent problem seen in gynaecological consultations. In about $80 \%$ of the cases an organic cause cannot be found so that treatment has to be purely symptomatic.

Coyne et al. $[17,18]$ have demonstrated that women with urge and mixed urge-stress incontinence have not only a significantly higher degree of incontinence but also a significantly poorer health-related quality of life than women with stress incontinence. In the NOBLE study (National Overactive Bladder Investigation) Steward et al. [19] determined the prevalence of mental stress caused by overactive bladder in the USA. The authors concluded that women are more strongly affected by urge incontinence than men, probably on account of their shorter urethras. Independent of gender, however, incontinent people have a markedly lower quality of life, higher depression scores and a poorer quality of sleep than continent persons.

\section{Psychosomatics of Incontinence \\ $\nabla$}

In part on the basis of our own long urogynaecological experience, a psychosomatic component can be observed or deduced from the case histories in a relatively large proportion of women with urge incontinence.

Since the 1980s various authors have attempted to identify mental causes of incontinence on the basis of psychometric examinations. Norton et al. [20] could not find any clear psychosomatic differences between women with urge incontinence and those with other forms of incontinence. Berglund et al. [21] found higher values for physical and mental anxiety and mistrust among women with urge incontinence whereas investigations by Freeman et al. [22], Macaulay et al. [23] and Lamm et al. [24] revealed higher values for anxiety and depression in patients with urge incontinence. This was confirmed in investigations by Chiara et al. [25]. These authors also found that women with urge and mixed urge-stress incontinence experienced anxiety more frequently than women with pure stress incontinence and that this was reflected (according to the results of the employed questionnaire) in insecurity and a general fear of illnesses. These patients also tended to develop psychosomatic reactions in dependence on the severity of their symptoms.

\section{Developmental Neurological Principles for the Development of Bladder Dysfunctions

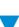

Control of bladder function is learnt in the first years of life. Physiologically it comprises a very complex system that is very prone to disorders. Neurophysiologically, micturition behaviour is a hierarchically structured control loop with cognitively conscious motor components and affective unconscious components. Thus, in the widest sense, micturition is concerned with the release, emission, stopping of urine with retention and holding back functions [26]. 
Table 1 Somato-/psychogenesis of voiding disorders.

\begin{tabular}{|llll} 
& Somatogenesis & $\rightarrow$ & Psychogenesis \\
Form of urinary incontinence & $\begin{array}{l}\text { stress incontinence, } \\
\text { tangible aetiology }\end{array}$ & mixed urge-stress incontinence, & $\begin{array}{l}\text { sensory/idiopathic } \\
\text { urge incontinence }\end{array}$ \\
\hline $\begin{array}{l}\text { Pollakisuria, dysuria, } \\
\text { infection, tumours of }\end{array}$ & motoric urge incontinence & urethral syndrome, \\
the lower urinary tract & interstitial cystitis & irritable bladder (pain bladder)
\end{tabular}

There is in principle an intentional relationship between the human psyche and bladder dysfunctions (incontinence, pollakisuria, dysuria, urge symptoms, voiding disorders): a somatic disease influences the mental state. It thereby encounters an individual mental condition that is significantly shaped by experience (socalled life stress). This explains the fact that similar situations are experienced and handled (coping) differently by different people. Thus, it is necessary to take the individual mental situation into account upon development of bladder dysfunctions.

The bladder is a storage organ that is and must be emptied from the very first day of life onwards. In contrast to other mammals, humans learn in their first years of life to control urination until a suitable place and time is available, i.e., until it is socially acceptable. In this period a child experiences on the one hand his/her power over the parents by voluntarily holding back excretions and on the other hand to be powerless against the external compulsion of "micturition on command", possibly with punishment. Rewards for micturition in the right place are a form of being noticed in the learning of bladder and bowel control that will again play a role in later life when the care recipient with incontinence needs to hold back micturition until he/she reaches a toilet.

Thus human excretions are of relevance from infancy to old age. Especially in the development stage of cleanliness education, there is a danger of psychopathological developments and psychosomatic impairments of bladder function [27].

From psychophysical points of view, the urogenital tract is an organ of desire, production and reproduction. This leads to an affect psychology of the pelvic floor consisting of three major affects: the aggressive affect of voiding ("wetting your pants", also tensing up in annoyance, anger), in retentive affects (retention, waiting until a suitable place for voiding is at hand, also cramping, e.g., as a result of previous trauma) and in depressive affects (reduced muscle tone in descent conditions) [28].

\section{Forms of Incontinence with Psychosomatic Origins \\ $\nabla$}

The forms of incontinence with rather psychogenic origins include:

- the painful bladder,

- the overactive bladder and

- recurrent urinary tract infections ( Table $\mathbf{1}$ ).

The symptoms represent a great burden for the patients, the therapy often creates major problems for the treating physician.

\section{Definitions}

Bladder pain syndrome (BPS) is defined as chronic pelvic pain that is thought to be bladder-related. In addition there is either a persisting urge to urinate or an increased frequency of micturition [29-31]. Interstitial cystitis (IC) is a subform with detectable ulceration.

An overactive bladder is defined by the (bladder) storage symptoms pollakisuria, imperative urge micturition and nocturia with or without incontinence, in the absence of local, metabolic, neurological or endocrinological pathologies [32].

A good survey of the definitions, pathogenesis and psychosomatic relationships of the sometimes difficult to delineate and sometimes overlapping topics "chronic lower abdominal pain in women," "somatisation disorders" and "somatoform disorders" can be found in the current guidelines of the DGPFG [33].

In urogynaecological practices, the bladder pain syndrome is mostly found in women who concomitantly report of sexual difficulties and suffer from chronic emotional tension. According to Diederichs [34] the mental correlate to this may be a latent sexual disorder, the somatic correlate of an anxiety disorder or, respectively, the result of a narcissistic affront.

Bodden-Heidrich R, Beckmann MW, Libera B et al. [35] have examined the psychogenic causes of overactive bladder. On the basis of an evaluation of psychosomatic tests they found that there was no causal relationship between incontinence and personality traits. On the other hand they considered it to be probable that the individual perception of incontinence had an influence on personality traits. The report published in 1978 by Frewen [36], after exclusion of an organic cause of overactive bladder, also described a psychogenic or emotional origin. Bladder training leads to a marked improvement of the symptoms after three months.

Chronic recurring cystitis can, according to Diederichs [37], be the expression of an unconscious "proximity-distance conflict", a "dedication disorder". It is postulated that this is related to urethral-aggressive elements and not being able/not wanting to let go. In contrast to an often expressed opinion, neither relationships between chronic recurrent urinary tract infections and sexual disorders or between sexual intercourse and cystitis nor a partner-related dependence of the sexual experience capability could be demonstrated. Instead a changed sexual activity and limited experience capability are rather the secondary consequences of chronic recurring cystitis.

The scientific discussion on this topic is also characterised by inhomogeneous definitions and a lack of systematic and precise investigations. It is possible that this is also an expression of helplessness in light of the complex and in part tabooed topic. It appears significant that no mention of the psychogenesis of overactive bladder is made in the current DGGG guidelines and that the guidelines were formulated without a corresponding scientific contribution. Further research is absolutely necessary.

\section{Psychosomatically Oriented Procedure}

\section{$\nabla$}

A psychosomatically oriented approach to micturition disorders consists of the following steps:

- Anamnesis of symptoms, including drinking and eating habits

- Psychosocial anamnesis including partnership and sexual disorders and indications of anxiety, depressiveness and somatisation and adaptation difficulties 
- Questions about neurological symptoms of other organ system

- General gynaecological anamnesis

- Urogynaecological diagnostics

The differential diagnosis should include various mental illnesses since symptoms such as pollakisuria and bladder voiding disorders can be part of a psychosocial complaint complex.

In daily routine, hints for a psychogenic causal component of micturition dysfunctions and bladder incontinence are, according to Bitzer [26], especially given when there is an obvious discrepancy between objective and subjective findings. Also the simultaneous occurrence of functional complaints such as obscure pain, bowel problems, fibromyalgia, etc. and mental symptoms such as anxiety and depressiveness as accompanying symptoms allows the assumption of a relationship. Furthermore the withdrawal of intimacy with the partner is an indication for a psychosomatic component as is also the mention of specific triggering situations. Moreover, somato- and psychogenesis frequently overlap ( Table 1). A multifactorial pathogenesis of micturition dysfunctions must always be taken into consideration.

\section{Urogynaecological Diagnostics}

$\nabla$

After the comprehensive case history, an urogynaecological examination is necessary.

- Clinical pelvic floor findings (neurological examination, speculum examination, assessment of vaginal environment, descent situation on pressing, stress test on coughing),

- vaginal and perineal ultrasound,

- hormone status,

- cystoscopy and

$\checkmark$ if necessary urodynamics

are absolutely essential for the exact diagnosis of bladder dysfunctions.

\section{Psychosomatic Differential Diagnostics \\ $\nabla$}

Various differential diagnostic considerations must be taken into account before a specific procedure can be initiated:

- masked sexual disorder

- communication disorder

- unconscious affect transformed to body level

- symptom of a severe psychiatric illness such as post-traumatic stress disorder, anxiety disorder, affective disorder or psychotic disturbance [38].

In order to take a bio-psycho-social anamnesis it is often sufficient to make use of the content and techniques of psychosomatic basic care.

In an open, face-to-face dialogue, questions should be asked about particular experiences in childhood, school education, relationship to parents and siblings, and moreover about school and professional training and the further course of life. With an attentive instinct, often not openly discussed conflicts, life events and trauma may be uncovered that can later be followed up and help to motivate the patient to participate in a deeper psychotherapeutic treatment [39]. Sometimes simple psychological questionnaires about the emotional state are useful.
It must be remembered that psychosomatic associations arise because difficult or traumatic events in the past have had to remain unprocessed and are thus not so easy to deal with now. The symptom indeed arises from their suppression and is thereby a suboptimal, neurotic solution. Whenever these burdensome experiences emerge from their suppressed state, resistance against their conscious awareness sets in. The therapist then needs patience and frustration tolerance.

\section{Therapeutic Concept}

Especially in cases of urge incontinence, the women often have endured lengthy periods of suffering, at best interspersed with sporadic improvements in the symptoms, but without being able essentially to completely eliminate the vulnerability of the bladder function. Psychosomatic treatment under consideration of mental components is also not possible without therapy for the somatic findings, but it does integrate the psychosomatic treatment with, e.g., accompanying dialogues. In cases with severe mental comorbidity a primary psychotherapy should be initiated [40].

The treatment consists of an individual therapy plan, accompanying dialogues, relaxation exercises and pelvic floor physiotherapy with, if necessary, nutritional advice and weight reduction as well as psychotherapeutic interventions.

\section{Aim of the Psychosomatically Oriented Treatment Concept}

The aim of treatment is an efficient improvement of the symptoms without permanent drug prescription, if at all possible with cure of the underlying disease. It should be noted that a patient will be open to a confrontation with her bladder dysfunction when she feels that her personality is considered as a psychophysical entity.

The referral of a patient with bladder dysfunction to a specialist for psychotherapy should be considered when constellations requiring in depth clarification are present and, of course, always when the patient herself realises that there could be a psychogenic cause and is motivated to effectively tackle her problem. To this end, the gynaecologist can provide important motivation help by the above-mentioned application of his/her psychosomatic basic competences.

The psychosomatically oriented treatment approach for female urinary incontinence, especially of the mixed and purely urge forms is in most cases more effective, the treatment costs under economic points of view are lower and the patient's satisfaction as well as most probably that of the treating physician are higher.

\section{Conflicts of Interest \\ $\nabla$}

None. 


\section{References}

1 Coyne KS, Wein A, Nicholson $S$ et al. Economic burden of urgency urinary incontinence in the United States: a systematic review. J Manag Care Pharm 2014; 20: 130-140

2 Buckley BS, Lapitan MC. Epidemiology Committee of the Fourth International Consultation on Incontinence, Paris, 2008. Prevalence of urinary incontinence in men, women, and children - current evidence: findings of the Fourth International Consultation on Incontinence. Urology 2010; 76: 265-270

3 Markland AD, Richter HE, Fwu CW et al. Prevalence and trends of urinary incontinence in adults in the United States, 2001 to 2008. J Urol 2011; 186: 589-593

4 Nygaard I, Barber MD, Burgio KL et al. Prevalence of symptomatic pelvic floor disorders in US women. JAMA 2008; 300: 1311-1316

5 Offermans MP, Du Moulin MF, Hamers JP et al. Prevalence of urinary incontinence and associated risk factors in nursing home residents: a systemic review. Neurourol Urodyn 2009; 28: 288-294

6 Milson I, Altman D, Lapitan MC et al. Epidemiology of urinary and faecal Incontionence and pelvic Organ Prolaps. In: Abrams P, Cardozo L, Khoury S, Wein A, eds. Incontinence. 4th ed. Plymouth, UK: Health Publications Ltd.; 2009: 35

7 Rendtorff $R$, Novak A, Tunn R. Normal pressure hydrocephalus as cause of urinary incontinence - a shunt for incontinence. Geburtsh Frauenheilk 2012; 72: 1130-1131

8 Burgio KL, Zyczynski H, Locher JL et al. Urinary incontinence in the 12 month postpartum period. Obstet Gynecol 2003; 102: 1291-1298

9 Franz HBG, Erxleben C, Franz A et al. Prevention of labor-associated pelvic floor injuries - what is known for sure? Geburtsh Frauenheilk 2012; 72: 804-808

10 Elbendawi A. Functional pathology of urinary bladder muscularis: the new frontier in diagnostic uropathology. Semin Diagn Pathol 1993; 10: 314-354

11 Hendrix SL, Cochrane BB, Nygaard IE et al. Effects of estrogen with and without progestin on urinary incontinence. JAMA 2005; 293: 935-948

12 Kirkland JL, Lye M, Levy DW et al. Patterns of urine flow and electrolyte excretion in healthy elderly people. Br Med J (Clin Res Ed) 1983; 287: 1665-1667

13 Dubeau CE, Simon SE, Morris JN. The effect of urinary incontinence on quality of life in older nursing home residents. J Am Geriatr Soc 2006; 54: $1325-1333$

14 Kelleher CJ, Cardozo LD, Khullar V et al. A new questionnaire to assess the quality of life of urinary incontinent women. $\mathrm{Br} J$ Obstet Gynaecol 1997; 104: 1374-1379

15 Bjelic-Radisic V, Dorfer M, Tamussino K et al. Psychometric properties and validation of the German-language King's Health Questionnaire in women with stress urinary incontinence. Neurourol Urodyn 2005; 24: 63-68

16 Hensel G, Kostal M, Göbel J. The effect of suburethral tape on the symptoms of overactive bladder. Geburtsh Frauenheilk 2014; 74: 63-68

17 Coyne KS, Zhou Z, Thompson C et al. The impact on health-related quality of life of stress, urge and mixed urinary incontinence. BJU Int 2003; 92: 731-735

18 Coyne KS, Kvasz M, Ireland AM et al. Urinary incontinence and its relationship to mental health and health-related quality of life in men and women in Sweden, the United Kingdom and the United States. Eur Urol 2012; 61: 88-95
19 Steward WF, Van Rooyen JB, Cundiff GW et al. Prevalence and burden of overactive bladder in the United States. World J Urol 2003; 20: 327336

20 Norton KR, Bhat AV, Stanton SL. Psychiatric aspects of urinary incontinence in women attending an outpatient urodynamic clinic. BMJ 1990; 301: 271-272

21 Berglund AL, Eisemann M, Lalos 0 . Personality characteristics of stress incontinent women: a pilot study. J Psychosom Obstet Gynaecol 1994; 15: $165-170$

22 Freeman RM, McPherson FM, Baxby K. Psychological features of women with idiopathic detrusor instability. Urol Int 1985; 40: 257-259

23 Macaulay AJ, Stern RS, Stanton SL. Psychological aspects of 211 female patients attending a urodynamic unit. J Psychosom Res 1991; 35: 1-10

24 Lamm D, Fischer W, Maspfuhl B. Sexuality and urinary incontinence. Zentralbl Gynäkol 1986; 108: 1425-1430

25 Chiara G, Piccioni V, Perino $M$ et al. Psychological investigation in female patients suffering from urinary incontinence. Int Urogynecol J Pelvic Floor Dysfunct 1998; 9: 73-77

26 Bitzer J. Psychosomatik der Miktionsstörung der Frau. In: Stauber M et al., Hrsg. Psychosomatische Geburtshilfe und Gynäkologie. Berlin: Springer; 1999

27 Bitzer J, Humburg J. Miktionsstörungen bei der Frau. In: WollmannWohlleben V et al., Hrsg. Psychosomatisches Kompendium der Frauenheilkunde und Geburtshilfe. München: Hans Marseille Verlag; 2008

28 Günthert EA. Psychosomatische Urologie. Stuttgart, New York: Schattauer; 2004

29 Rodewig K, Jansen PL. Somatoforme autonome Funktionsstörungen in der Urologie. Psychotherapeut 2003; 48: 336-341

30 Engeler D, Baranowski AP, Elneil S et al. Chronic pelvic Pain. In: Engeler D, Baranowski AP, Elneil S, Hughes J, Messelink EJ, Oliveira P, van Ophoven A, de C. Williams AC, eds. Guidelines on chronic pelvic Pain. Arnhem, The Netherlands: European Association of Urology (EAU); 2012: 10-28

31 Siedentopf F, Sillem M. Chronischer Unterbauchschmerz der Frau. Schmerz 2014; 28: 300-304

32 Heidler H, Gauruder A, Schulz-Lampel D et al. Die überaktive Blase. S2kLeitlinie. AWMF-Leitlinien Register Nr. 015/007, 1.6.2010

33 Siedentopf F, Kölm P, Kentenich H et al. Chronischer Unterbauchschmerz der Frau. S2K Leitlinie. AWMF-Leitlinien-Register Nr. 016/001, in Überarbeitung

34 Diederichs P. Urologische Psychosomatik. Bern: Hans Huber; 2000

35 Bodden-Heidrich R, Beckmann MW, Libera B et al. Psychosomatic aspects of urinary incontinence. Arch Gynecol Obstet 1999; 292: 151158

36 Frewen WK. An objective assessment of the unstable bladder of psychosomatic origin. Br J Urol 1978; 50: 246-249

37 Diederichs $P$. Urogynäkologische Erkrankungen. In: Weidner $\mathrm{K}$ et al. Hrsg. Leitfaden Psychosomatische Frauenheilkunde. Köln: Deutscher Ärzte-Verlag; 2012

38 Neises M. Unterbauchschmerz. In: Bitzer J, Hoefert HW, Hrsg. Psychologie in der Gynäkologie. Lengerich: Pabst Science Publishers; 2014: 203-216

39 Rudolf G, Henningsen P. Die psychotherapeutische Behandlung somatoformer Störung. Z Psychosom Med Psychother 2003; 5: 3-19

40 Bodden-Heidrich R. [Psychosomatic aspects of urogynaecology: model considerations on the pathogenesis, diagnosis and therapy]. Zentralbl Gynakol 2004; 126: 237-243 